\title{
Bid'ah in Concept of Maslahah Mursalah and Istihsan According to Imam asy-Syathibi
}

\author{
Yahdi Dinul Haq1, Hafizah Muchtia², Zia Alkausar Mukhlis ${ }^{3}$ \\ ${ }^{1}$ Institut Agama Islam Negeri Bukittinggi \\ e-mail: yahdidehaq@gmail.com \\ 2Institut Agama Islam Negeri Batusangkar \\ e-mail: hafizahmuchtia2015@gmail.com \\ 3Institut Agama Islam Negeri Bukittinggi \\ e-mail: ziamukhlis4@gmail.com
}

\begin{tabular}{|l|l|l|}
\hline Received: 17-05-2021 & $\begin{array}{l}\text { Revised: 15-09-2021, } \\
\text { 29-10-2021 }\end{array}$ & Accepted: 10-11-2021
\end{tabular}

Abstract: The problem of figh that is always developing demands the realization of the argument that is the background of the legal basis for the act of figh. Istihsan and mashlahah mursalah are legal grounds accepted by the jurists, although there are some who reject their use. Asy-syathibi actually provides a unique interpretation by relating it to the term bid'ah which is the benchmark for the limits of the development of Islamic law so that it is always in accordance with the direction of the Shari'a.. The purpose of this paper is to explore the opinion of the Al-Imam asy-Syathibi regarding heresy as well as his opinion on the reasons some people base their bid'ah deeds with mashlahah mursalah and istibsan. So that the Al-Imam asy-Syathibi refused to use mashlahah mursalah and istibsan as the basis for beretical deeds.
Abstrak: Masalah fiqh yang selalu berkembang menuntut terwujudnya dalil yang melatarbelakangi landasan hukum perbuatan figh. Istihsan dan mashlahah mursalah merupakan dasar hukum yang diterima oleh para fuqaha, meskipun ada sebagian yang menolak penggunaannya. Asy-syathibi justru memberikan tafsir yang unik dengan mengaitkannya dengan istilah bid'ah yang menjadi tolak ukur batasan pengembangan hukum Islam agar selalu sesuai dengan arahan syariat. tulisan ini adalah untuk menggali pendapat Al-Imam asy-Syathibi tentang bid'ah serta pendapatnya tentang alasan sebagian orang mendasarkan perbuatan bid'ahnya dengan mashlahah mursalah dan istihsan. Sehingga Al-Imam asy-Syathibi menolak menggunakan mashlahah mursalah dan istihsan sebagai dasar perbuatan sesat.

Keywords : Abu Ishaq asy-Syathibi, Bid'ah, Mashlahah Mursalah, Istibsan.

\section{INTRODUCTION}

$\mathcal{T}$

he Qur'an is that the source of the Muslim's teaching, which is revealed as guidelines for the hereafter for mankind. Therefore, it's certain that the content of the Qur'an covers all aspects of human life. It's just that the knowledge contained within the Qur'an is usually global. Furthermore, the role of the Prophet Muhammad (peace be upon him) as a messenger of Allah explained the common things.
One of the functions of sunnah is that the explanation of the Qur'an. Both the words, deeds and taqrir of the Prophet Muhammad are the second source after the Qur'an. But it must be recognized with the event of the days and spread of Islam throughout not all the dissolution of generality are often resolved with the Qur'an and sunnah. the issues that arise demanding the existence of law to unravel the case make shahabah gather (ijma') to 
determine the law ( ijtihad). (Habibullah, 2017)

This condition didn't long because the authorization of Islam was wider and therefore the companions radiated to varied regions, wanting them to try and do their own legal istinbath. This results in the event of legal methods. within the next period, various legal istinbath methods like qiyas, istihsan, mashlahah mursalah, urf, istishab, and so on.

Although the development of the method of legal determination provides a solution to the problem that occurred, there are still differences between scholars in responding to the method. Al-Imam asShafi'i rejected the use of istihsan as one of the methods of ijtihad (Nabilah et al., 2021). On the other hand, Al-Imam Abu Hanifah uses istihsan in one of his ijtihad methods (Habibullah, 2017). Likewise with Al-Imam Malik who triggered mashlahah mursalah as one of his methods of ijtihad (Rosyadi, 2013). They have their own views in their own ijtihad methods.

The differences of scholars above provide room for mujathids to explore new laws that often refract to bid'ah. Among the examples is the existence of the term bid'ah hasanah because it is almost similar to mashlalah mursalah and istihsan. The likeness in question is the existence of something new but good for religion. Al-Imam asy-Syathibi considers that calling bid'ah hasanah with mashlahah mursalah and istihsan is wrong. Because according to him there is no such thing as bid'ah hasanah.

Based on the background above, the author wants to examine (1) What is the opinion of Al-Imam asy-Syathibi about bid'ah. (2) How the Al-Imam asy-Syathibi explains the difference between bid'ah with mashlahah mursalah and istihsan.

\section{RESEARCH METHODS}

Solving the issues above, the author uses library research with the Qualitative approach. So in this case, what the author does is to collect books that are related to this research, then record and process them based on literature data that are related to the subject matter discussed.

This study uses primary and secondary data sources. Primary data is direct research data on subjects as a source of information studied. The sources of the data in this study are al-I'tishâm, fatâwa alSyâthibiy, al-Muwafaqât by Abu Ishaq Ibrahim bin Musa bin Muhammad alLakhmi asy-Syathibi al Gharnathi and also the book of Al-Imam al-'Izzuddîn bin Abdis Salâm Qawâ'id al-Ahkâm fi Mashâlih al-Anâm. Secondary data is data that supports or as additional data to primary data. As secondary data in this study are books related to bid'ah, in addition to textbooks secondary materials can be writings about fiqh such as journals, articles, scientific works such as thesis, thesis, dissertation, and contemporary writings related to bid'ah. The usefulness of secondary legal material is to give researchers some sort of "clue" in which direction the researcher is stepping as inspiration for the author.

\section{RESULT AND DISCUSSION}

\section{Overview of Bid'ah}

The meaning word of $(ب د)$ is the creation of something new that there was no previous excuse, (As-Syathibi, 1988) bid'ah according to lughat (etymology) comes from the word - بدع - بعبد بديع (Munawwir, 1997) meaning holding something new without any previous examples. This meaning is as the word of Allah says in the Qur'an that reads: 


$$
\text { بَدِيعُ السَّمَاواتِ وَالأرْضِ }
$$

"God is the creator of heaven and earth." AlBaqarah: 117). (Sitanggal et al., 1992)

God created the heavens and the earth with a form and form that no example predates it (Sabki et al., 2012). And also in accordance with the word of Allah in Surah al-Ahqaaf verse 9 which reads:

$$
\text { قُلْ مَا كُنْتُ بِدْعًَا مِنَ الرُسُسلِ }
$$

"Say,"I open the first ofthe Apostles." (QS. Al-Ahqaf: 9)(Shihab, 2002)

Concerning the above verse Al-Imam ibn al-Kathir in his commentary explains: "What I bring is the same as the previous Prophets. Then why do you deny and stay away from my apostolic? Allah has sent the Prophets before me to all mankind" (Ash-Shabuni, 2011). Sheikh Ali alShabuniy further explained that under lafaz al-bida' and al-badi' means things that have not existed before or something new. (Al-Shabuniy, 1981)

So when it is said ابتدع فلان بدعة (the fulan has done bid'ah), it means that the fulan has begun to hold or make a way that has never been preceded by others or no one has ever preceded him (AsSyathibi, 1988).

Ibtida' (making something new) there are two kinds: First, Ibtida in matters of habit (worldly problems) such as recent discoveries (modern). This is fine because the law of origin in custom) is mubah. Second, Ibtida' is in matters of religion, and this is illegal. Because the law of origin in the field of religion is tauqif (limited to revelation). (Fachrudin \& et.al, 2012)

The word bid'ah is also used to say something that is considered good and beautiful and nothing equals, such as the
Arabic word هذا أمر بديع (this is a beautiful thing or affair). (As-Syathibi, 1988)

Among the uses of the word bid'ah in this sense is the word of a man who came to meet the Prophet"Innii ubdi'a bii fahmilnii." (I am exhausted, please give me provisions) so the Prophet said, "I have none." A man said, "O Messenger of Allah, I will show him to those who can help him." The Prophet said, "Whoever shows good, he will be regarded as the reward of those who do it." (Al-Basithi, 1932)

Ibn Manzhur said in lisanul 'Arab:

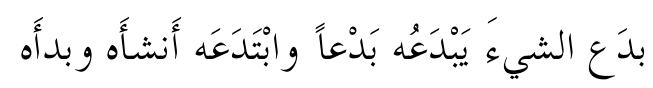

"To have made something heretical (past), to make it (present) and bad'an (masdar) means to hold and begin" (Manzhur, 1955)

Bid'ah according to terminology by explanation of the scholars is:

Al-Fairuz Abadiy in Qamusul Muhith, bid'ah is:

$$
\begin{aligned}
& \text { الحدث في الدين بعد الإكمال أو ما استحدث بعد } \\
& \text { البي صلى الله عليه و سلم من الأهواء والأاعمال }
\end{aligned}
$$

"Something new in religion after perfection or something that was held after the death of the Prophet (peace be upon him) from some desire of lust and some deeds"(Abadii, 2008)

Asy-Shammani in al-Ibda' fii Madharil Ibtida', bid'ah is:

$$
\begin{aligned}
& \text { ما أحدث على خحلاف الحق المتلقى عن رسول الله }
\end{aligned}
$$

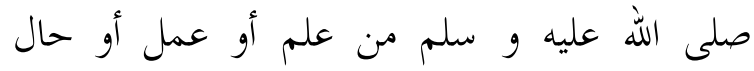

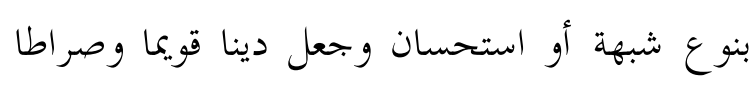

$$
\begin{aligned}
& \text { مستقيما }
\end{aligned}
$$

"Something that has been made up by violating the haq (truth) received from the Prophet (peace be upon him), either from knowledge or deeds or circumstances with a kind of syubhat (vague information) or because of something that is considered good and makes a religion that is a good and a straight path." 
The bid'ah delivered by 'Izzudin bin Abdussalam is:

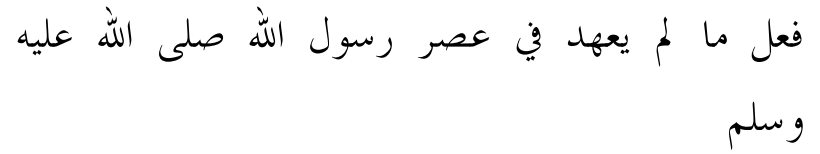

It means: doing things that have not been done even in the time of the Prophet Shallallahu 'alaihi wa sallam. (Aziz bin Abdi Salam, 2000)

Al-Imam al-Syatibi, a jurist of the Maliki school, said that the bid'ah is a tariqah (way or method) that was created to resemble sharia in religion to be lived as worship to Allah (Dahlan, 1997: 217). More clearly Bid'ah according to al-Syatibi quoted from the book ofal-'Itisham is

$$
\begin{aligned}
& \text { فالبدعة إذن عبارة عن (طريقة في الدين مخترعة } \\
& \text { تتضايي الشرعية يقصد بالسلوك علييا المبالغة في } \\
& \text { التعبد لل سبحان) }
\end{aligned}
$$

Bid'ah is a term about ordinances in religion that are deliberately made and resemble sharia, with the aim of expressing it in the form of behavior (deeds) that rely on it excessively, especially in worshiping Allah. (Sabki et al., 2012)

As for determining the boundaries of bid'ah scholars differ opinions. Based on the above definition, the notion of bid'ah can be classified into the aspect of language and aspects of sharia(Araby, 2017). In the language aspect the word bid'ah is used to name all new things, while in Shari'ah the word bid'ah is only used to describe new ways or methods that have no basis in the Qur'an and the Sunnah of the Prophet. (Sabki et al., 2012)

Groups that hold on the aspect of language divide bid'ah over two forms, namely bid'ah hasanah or bid'ah mahmudah and bid'ah sayyi'ah or bid'ah mazmumah. Bid'ah hasanah is bid'ah following the purpose of Syara', even though it is not done by the Prophet (peace be upon him). Bid'ah sayyi'ah is a bid'ah that is not following the purpose of Syara' (Sabki et al., 2012). Even Izzuddin stated on another occasion the division of Bid'ah there are five kinds (Nazaruddin, 2017), equated with five laws concluded by fiqh scholars for taklif,wajib, haram, sunnah (mandub), makruh and ibahah.

The group that holds on to the second understanding bid'ah (which refers more to the aspect of sharia), explained that the bid'ah is formed divided over, namely bid'ah al-'adiyah (bid'ah in daily habits) and bid'ah at-ta'abudiyah (bid'ah in worship). Bid'ah adiyah is a worldly habit that has been handed over by the prophet (peace be upon him) to his people to be implemented or abandoned.

In this group what is declared as bid'ah is bid'ah in matters concerning worship. As for the bid'ah al-wajibah and bid'ah al-mandubah put forward by the bid'ah group the aspect of language is al-mashlahahh al-mursalah (maslahat) and also istihsan. Therefore collecting the Qur'an, spreading knowledge that supports the understanding of the Qur'an excluding bid'ah, is one form of al-maslahah al-mursalah. Bid'ah is limited to the things that worship (Dahlan, 1997).

\section{Difference between Bid'ah With Mashlahah Mursalah and Istihsan According to Asy-Syathibi}

\section{Biography of Al-Imam asy-Syathibi}

Al-Imam asy-Syathibi was an 8thcentury Muslim intellectual H./14 A.D. from Andalusia, precisely in a region of the Iberian peninsula that is now part of Spain and Portugal (Mubarok, 2008). More related to his personal data is detailed as follows:

The name of Al-Imam asy-Syathibi agreed upon by historians is Ibrahim Ibn 
Musa ibn Muhammad. The chew that was used on him was Abu Ishaq, none of the historians knew anything the names of his children and their numbers. The nasab mentioned by historians is al-Lakhmi. The nasab was presented to Lakhmu ibn 'Adi. ('Ali, 1998).

Historians refer to al-Gahrnathi and asy-Syathibi. The word al-Gharnathi refers to the kingdom of "Garnathah" which lived during the time of asy-Syathibi RA. While asy-Syathibi then the "Syatibah" in the dictionary refers to the name of the region. The city in eastern Andalusia is east of Cordoba. ('Ali, 1998)

According to his name, historians suspect that he came from the descendants of the Arab tribal family, Lakhm, who lived in Syatibah (Xativa or Jativa), a city south of Valencia known as a paper producer in Medieval Spain. (Mubarok, 2008)

The year of his birth are unknown, as his family background (Abdullah, 1996). As far as can be traced, Muhammad Abu al-Ajfan has established the year of his death of 720 Hijri based on the date of his first teacher died, Sheikh Abu Ja'far Ahmad ibn Ziyat (w. $728 \mathrm{H}$ ) and it is a year that is close to the birth of Al-Imam as-Syathibi about $720 \mathrm{H}$. ('Ali, 1998)

Al-Imam asy-Syathibi grew up in the region of Granada at the end of the Islamic kingdoms (Abdurrahman, 1998:45) and his intellectual history was established in the city that became the capital of the Kingdom of Banu Nasr. His youth coincided with the reign of Sultan Muhammad V al-Ghani Billah which was a golden age for Granada. (Andriyaldi, 2013)

Al-Imam asy-Syathibi was in a time of important changes. Granada in the 14th century experienced various changes and developments in political, social, economic and legal matters that would later affect the mindset and ijtihad asySyathibi (Andriyaldi, 2013). Perhaps it was the above that made the priest of AshSyathibi remain in Granada and did not travel out of Andalus until God had been entrusted.

Asy-Syathibi's intellectual career is widely known through the statements of the students and the recognition of current scholars. One of his disciples, Ibn 'Ali AlMujari (d. 801 H.), stated that asyShaathibi is asy-Shaykh al-Al-Imam,al'Allamah (very knowledgeable) who is famous and special. Ibn Marzuq (d. 805 H.) states that asy-Syathibi is asy-Shaykh al-Ustaz, jurist, al-Imam, researcher, 'allamah and pious. (Al-Ajfan, 1985)

As one of the scholars, who are entitled waratsah al-anbiya', asy-Syathibi has become a reference of the community and the ruler in solving various religious problems. This predicate led him to a passion for interacting with society and encouraged him to deepen his knowledge through. The logical consequence of expertise is that he works as a mufti, alImam (khatib), teacher, and prolific writer. (Al-Ajfan, 1985)

As a mufti, asy-Syathibi gave many religious fatwas. Is this career as mufti appointed by the ruler or just the recognition of society? This question is important, because in the Islamic legal system in Andalus found fatwa institutions, whose muftis are appointed by the ruler and they consist of fuqaha. There is no information about his appointment as mufti by the ruler, so it is strongly suspected that his career as a mufti is only a recognition from the public only, not appointed by the ruler. (Duski, 2006)

As a teacher, asy-Syathibi taught to develop his knowledge through students, 
among others: Abu Yahya ibn Muhammad ibn 'Asim, an 'alim, Khatib, writer, heir of asy-Syathibi thought. Then Abu Bakr al-Qadhi, brother of Abu Yahya Muhammad al-Bayani, a Granada faqih. Then Abu Ja'far Ahmad, who in addition to being a student is also a discussion partner. Abu Abdillah Ibn Marzuq suggested that asy-Syathibi often discussed the book of al-Muwafaqat with his disciple. In the presence of these disciples, asy-Syathibi taught books including Alfiyah ibn Malik, Kitab Sibawaih, Mukhtasar ibn al-Hajib, al-Muwatta' AlImam Malik, and of course his works. (Duski, 2006: 39)

During the asy-Syathibi period, Granada was hit several times by internal political conflicts. A succession of power often proceeds through bloody struggles. But there is no data to indicate asySyathibi's alignment with either of the warring parties for power. The political world does not seem to attract the interest of asy-Syathibi. Instead, he devoted all his attention and intellectual interest to solving two major problems that spread among Granada society at that time: taklid and bid'ah. (Mubarok, 2008)

According to asy-Syathibi, the biggest cause of spreading taklid and blind fanaticism among the inhabitants of Granada was their tendency to limit attention only to secondary problems(furu') without trying to trace the fundamental principles (proposals) of Islamic teachings. This was one of the driving factors of al-Syathibiy to write his great work, al-Muwafaqat. (Al-'Abidi, 1992)

Asy-Syathibi did not silent watching bid'ah spread widely. He wrote Kitab al-I'tisam, a work that contains to return to the pure teachings of Islam and abandon all bid'ah. Not only that, but asySyathibi also strongly opposed the scholars who silenced, or even supported, heretical practices. In his efforts to make social and religious improvements, asy-Syathibi was not unaware of the severe risks he faced. It was marked by his expression that perishing following the Sunnah is salvation and no one will give an accident but by the decree of Allah. (Mubarok, 2008)

Translators have agreed on the year of his death, some specifying his death on the month, some specifying the date of that month, and some mentioning the day of his death, and his presentation as follows: His disciple Abdullah al-Majari said he died in Sha'ban in $790 \mathrm{H}$. The same thing was also said by Ahmad Bab alTanbakti, al-Maraghi in his book Fathul Mubayyin fi Thabaqat al-Usuliyyin, ibn alQadhi in Luqtul Faraid and Ahmad in the book of al-Wafiyat who stated, he died on Tuesday in Sha'ban in 790 H. ('Ali, 1998)

\section{Opinion of Al-Imam asy-Syathibi on Bid'ah}

Bid'ah has been discussed by scholars both in classical and contemporary times, regarding its nature and influence in a practice. Al-Imam asySyathibi in al-I'thisam defines bid'ah is:

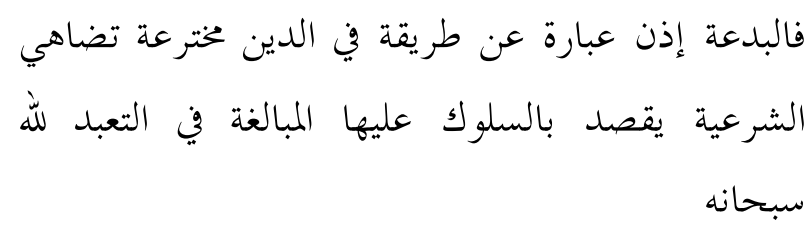

"Then if so, bid'ah is the thariqat (way) that is made up in religion, which matches (resembles) the law of shari'ah, which is meant by doing it, is an exaggeration in devoting oneself (worship) to Allah the Most Holy"(AsSyathibi, 1988)

And: 


$$
\text { بالسلوك عليها ما يقصد بالطريقة الشرعية الدين مخترعة تضاهي الشرعية يقصد }
$$

"And bid'ah is a way that is made up in religion, which resembles the law of shari'ah, which is meant by doing it is what is meant by the way (way) of doing the law of shari'ah" (As-Syathibi, 1988)

According to asy-Syathibi the first definition of bid'ah does not include customary affairs (worldly) into the meaning of bid'ah, but only especially on the issue of worship only. While the second definition puts customary affairs into the scope of bid'ah (As-Syathibi, 1988). So bid'ah surrounds the affairs of worship and custom.

The explanation of the definition can be read as quoted by asy-Syathibi, namely: the meaning of the word according to him, that understanding is something that has been set to be lived, which the heretic rests the new thing on religion. For if the new way is in worldly trouble, it does not belong to the category of bid'ah, such as making factories, establishing the state, even though it has not been known before.

Furthermore, the meaning of the word "rivaling (resembling) shari'ah" in that sense means that it resembles the ordinances that exist in Shari'ah even though the act does not include shari'ah, even contrary to shari'ah. Among others (As-Syathibi, 1988):

a. Determining certain restrictions of charity that previously there were no special restrictions by the Shari'ah, for dexample, if there is a person vowing to fast by standing alone and not sitting or specializing to sunbathe alone without shelter, with the intention of the specialization is in the framework of worship. Also included with choosing food and clothes without any reason.

b. Practice certain ordinances and conditions of worship that there are no special provisions before, such as dhikr with the condition of one voice at the same time and celebrating the birthday of the Prophet (peace be upon him).

c. Stick to certain worship and at certain times, which have no decrees in the Shari'ah, such as sticking to the fast of the middle of Sha'ban and reviving the night and other similar practices.

So certain ways that do not match or resemble the provisions of Shari'ah, are not a matter of bid'ah but only customs (Qadir \& Saqqaf, 2003). With the above limitations, it can be understood that the al-Imam of asy-Syathibi concluded that custom does not include bid'ah.

While the word "which is meant by doing it, is to doubt devoting (worship) to Allah" in the above definition according to asy-Syathibi is the essence of bid'ah. That is the purpose and purpose of the bid'ah that causes the act to be forbidden. Whereas in fact it is not so, even contrary to sharia when viewed in several aspects, among others (As-Syathibi, 1988):

1. provide certain restrictions, such as people who are nazdar to fast while standing and not sitting, sunbathing and not sheltering, or specializing in breaking social relations for worship, and limiting the eating of food and wearing certain clothes for no reason.

2. Familiarize certain ordinances and certain worship requirements, such as dhikr with the condition of one voice at the same time and make the birthday of the Prophet (peace be upon him) a celebrated day.

3. Stick to certain worship and a certain time, which has no decree in the Shari'ah, 
such as sticking to the fast of Sha'ban and reviving the night.

While the second definition, according to asy-Syathibi the difference of definition on the purpose of its purpose is made. In this definition in the last section, it is mentioned: "what is meant by doing it is what is meant by the way (way) of doing the law of Shari'ah." This is the true meaning of bid'ah because this is the main purpose of something (Sabki et al., 2012). It means that Shari'ah (Islam) comes none other than for the benefit of human beings both in the world and in the world so that they obtain the perfection of life. This is what the one who does bid'ah wants. That the affairs of the world and the hereafter with the bid'ah deeds that he did became perfect. Although there are two heretical definitions, Al-Imam asy-Syathibi in practice is inclined to the first bid'ah definition.

According to al-Imam asy-Syathibi that bid'ah can be related to customs or worship. If it is related to custom then what the heretic wants so that all world affairs are in perfect good, if it is related to worship then what the heretic wants is to perform the worship as perfectly as possible to obtain the highest position in the hereafter, and practice the verse of the Qur'an that reads:

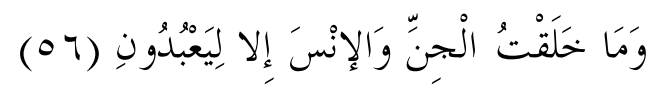

And I did not create the jinn and men except that they might serve Me. (QS. Al-Zariyat: 56)

\section{Correlation of bid'ah with Mashlahah mursalah and Istihsan According to asy- Syatibi}

The important point of discussion on bid'ah according to al-Imam asySyathibi is his discussion of opinions that connect some of the terms ushul fiqh as the basis for being called bid'ah or not a matter. According to him some people who lack his understanding of ushul fiqh experience confusion in understanding maslahah mursalah, istihsan, and bid'ah. Most of them would assume that part of mashlahah mursalah is heretical. They rested his assumptions on friends and tabi'in and made it an argument to justify bid'ah in worship. (As-Syathibi, 1988)

Based on their assumptions, mashlahah mursalah is a form of legal adjustment of a case with no basis for certain propositions. So it does not have a particular syar'i backrest, nor is it an acceptable form of qiyas. (As-Syathibi, 1988)

Based on this they assume that mashlahah mursalah is a form of bid'ah that is considered good, because it is returned to religious matters that have a certain maslahat. As for the basis of their thought related to the ability of bid'ah is if mashlahah mursalah accepted, means good bid'ah must be accepted, because the source of the taking of both is the same. Conversely, if good bid'ah is unacceptable, then mashlahah mursalah is also unacceptable. Similarly, istihsan, because istihsan is also a way of establishing the law without the basis of the proposition (As-Syathibi, 1988).

On this issue, in the book of alI'tisham Al-Imam asy-Syathibi explained at length that bid'ah is different from mashlahah mursalah. Asy-Syathibi concludes:

a. Bid'ah is the opposite of mashlahah mursalah, because it is the object of maslahah mursalah is a thing that can be understood the meaning of its purpose in detail by reason while the object of bid'ah is worship which is essentially incomprehensible meaning in detail. (As-Syathibi, 1988) 
b. Maslahah mursalah is intended to keep affairs that are basic and only as an intermediary or intended to relieve taklif (burden). so as opposed to bid'ah which is calculated to add burden (in taklif), so that it is contrary to the principle of mashlahah mursalah. (AsSyathibi, 1988)

Before making this thought, asySyathibi provided several illustrations of the practice of mashlahah mursalah,for example, the policy carried out by Umar bin al-Khathab about being able to kill a group of people for killing one person (which is forbidden to kill).

According to him, the basis of this acquisition is mashlahah mursalah, because there is no clear nash that indicates such a provision. The good side of this rule is so as not to undermine the provisions of the qishas law. Asking others for help so that they are not alone in killing gives way for someone to kill others when it is known that there is no law of qishas in the matter. If anyone says it is bid'ah in the Shari'ah, then according to asy-Syathibi the reason they were killed is that they participated in the murder. The condition conveyed by asy-Syathibi is a benefit that encourages killing others. So this is not bid'ah or a new thing in Shari'ah, because it has the purpose of maintaining the purpose of establishing shari'ah qisas, namely in terms of protecting the blood of haram. (As-Syathibi, 1988)

Another example is the codification of the Qur'an. At that time the companions of the Prophet agreed to collect the mushaf of the Qur'an, even though there were no nash that showed the command to collect. But the companions saw it as a benefit, which was clearly following the rules of the Shari'ah. Because this kind of action is classified as trying to guard against the Shari'ah, so the command to keep the Qur'an is something that has been understood. And also as an effort to prevent disputes in the matter of the source of shari'ah, namely the Qur'an. (As-Syathibi, 1988)

Asy-Syathibi made a formulation of the concept of mashlahah mursalah, which he made the basis of a foothold for in reviewing the matter of bid'ah, namely as follows:

1. Mashlahah mursalah must be under the purpose of Shari'ah. Thus mashlahah mursalah which is set always pay attention to the rules or propositions of shari'ah. (As-Syathibi, 1988)

2. asy-Syathibi states that the scholars remind that this mashlahah mursalah is not used in things that cannot be reached by the meaning of the mind because this mashlahah mursalah its scope on things that can be understood by reason. This is so as not to allow reasoning to enter into the problem of worship and other things of Shari'ah which is a matter of worship, such as ablution, prayer, fasting, hajj, and so on. (As-Syathibi, 1988)

3. Mashlahah mursalah is applied to keep things that are basic (very important) and aim to eliminate severe problems that usually arise in religious matters. And it is included in the rule: "something whose absence makes it imperfect an obligation, so it is punished by duty." So mashlahah mursalah includes intermediaries (wasail), not the purpose (maqasid). And its enactment is to reduce heavy problems (reduce burdens), not to increase the burden. (As-Syathibi, 1988)

The above explanation states that it is impossible with the permissible mahslahat mursalah asy-Syathibi allows bid'ah and adds to matters of a sunnah nature. Because bid'ah is the object of worship, and also because bid'ah also adds 
to the burden, which is contrary to the principle of mashlahah mursalah that lightens the burden. In conclusion, there is no connection between the heretic and maslahah mursalah (As-Syathibi, 1988).

While related to the relevance of bid'ah and istihsan according to asySyathibi, it appears when there are people who do bid'ah by basing bid'ah on the expression: "this is bid'ah mustahsanah" (bid'ah which is viewed well based on istihsan). It means that he based the deed on istihsan, which according to him istihsan is something that is considered good by Mujtahid with his reason and also his opinion. So that opinions like this will give rise to mustahsin (people who judge well), even though this mustahsin deed makes the perpetrator put forward reason rather than sharia. (As-Syathibi, 1988)

The definition of istihsan as above also resulted in the ability of reason to reject a sharia proposition. And it is can be assumption of a layman with the law of syar'i on a case can be used because of his skills in other scientific fields. (AsSyathibi, 1988)

The proposition used as the basis of the act is the word of God (As-Syathibi, 1988):

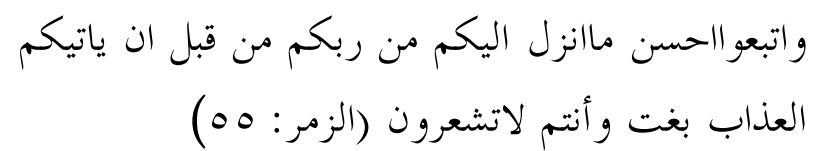

"And follow the best that has been sent down to you from your Lord before the punishment comes to you suddenly, while you do not realize it."

And the word of God:

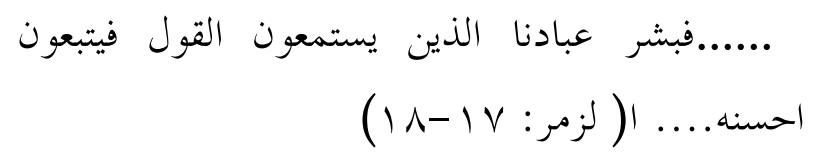

"So please pleased you, my servants. Who listens to words and follows what is best among them.
And also, a hadith:

$$
\text { فماراى المسلمون حسنافهو عندالله حسن (رواه احمد ) }
$$

"What is seen as good by the Muslims is good, and good according toAllah."

Al-Imam asy-Syathibi said according to those who are meant by the above proposition is what they see with their minds. If it is considered good syar'i (their opinion) there is no right for them (for their reason) to declare it good, because the concept of sharia itself is free from the good judgment they express with their reason (As-Syathibi, 1988). So it is clear that the arguments they use do not strengthen the arguments they have expressed above. Istihsan like this is what the al-Imam of Shafi'i denies with his famous agreement, "Who ever istihsan means he has made a new Shari'ah." (AsSyathibi, 1988)

From the ushul fiqh side, itself is alImam malik and al-Imam Abu Hanifah declared istihsan as the source of the law. They define the istihsan differently from that conveyed by the first istihsan definition above. The definition of bid'ah according to al-Imam Malik and Abu Hanifah proposed by asy-Syathibi is to practice the strongest proposition between the two propositions. Every general proposition that applies continuously and if analogous and suitable, then according to Al-Imam Malik and Abu Hanifah it can be devoted to any proposition, both in zahir lafaz and its meaning. Al-Imam Malik mngistihsankan takhshis with mashlalah, while al-Imam abu hanifah istahsishkan with istihsan. If what is meant by istihsan with the definition conveyed by Maliki and Hanafi above, then istihsan is considered as a proposition. and like this is also not denied by the Al-Imam Shafi'i so it is clear that there is no reason for mubtadi' (one 
who makes bid'ah) by underlying it with istihsan. (As-Syathibi, 1988)

Following the presentation above $\mathrm{Al}$ Imam asy-Syathibi tried to classify that the meaning of the words mashlahah mursalah and istihsan used by people who base their opinions with two sources of Islamic law is very wrong. Because according to asySyathibi mashlahah mursalah and istihsan is intended not as its meaning in language, namely mashlahah mursalah which is interpreted by deeds that contain health and istihsan with acts that contain goodness. But it must be returned the meaning of the word mashlahah mursalah in accordance with what was desired by Al-Imam Malik. The meaning of the word mashlahah mursalah according to Al-Imam Malik is a mashlahah that has no cancellation from nash and is also not clearly mentioned by nash but this mursalah maslahat should not contradict nash as the main source (Herawati, 2014). So it can be seen, actually making mashlahah mursalah as a source legalizing bid'ah is very wrong.

Likewise, the meaning of the word Istihsan must also be returned to the meaning of the word carried by Al-Imam $\mathrm{Abu}$ Hanifah, which the opinion of $\mathrm{Al}$ Imam Abu Hanifah on the issue of bid'ah can be found from the opinion of one of the Hanafiyah scholars, Al-Imam alSarakhshi. He defines istihsan in terms of abandoning qiyas and practicing stronger than that, because there is a proposition that wants it, following human welfare. (Winarno, 2019)

So according to the author, when a person does ijtihad to establish a law, it is required that the mujtahid understand the methods he uses, so as not to be mistaken in resulting in ijtihad. A mujtahid needs to understand the terms in ushul fiqh following the Al-Imam who uses the term for jihad. Of course, when mujtahid uses the rule of mashlahah mursalah then returned to the definition delivered by $\mathrm{Al}$ Imam Malik. Likewise, with istihsan, the meaning is also returned to Al-Imam Abu Hanifah. So to justify good bid'ah (hasanah) with good reason mashlahah mursalah and istihsan both have no reason with bid'ah hasanah is very wrong. TThe rebuttal submitted by $A l-$ Imam ash-Syathibi to those who make mashlahah mursalah and istihsan as legalization of bid'ah acts is very appropriate in order to maintain the purity of shari'ah from hands that disrupt Islamic shari'ah.

\section{CONCLUSION}

Based on the above explanation, it can be concluded that al-Imam asySyathibi understands bid'ah according to the meaning of sharia, not from the aspect of language, so according to asy-Syathibi bid'ah, it is only on the aspect of worship. It can be understood from his definition of bid'ah: Bid'ah is a term about ordinances in religion that are deliberately made and resemble sharia, to express it in the form of behavior (deeds) that rely on it excessively, especially in worshiping Allah.

This definition explains that if new action occurs outside the scope of worship then it is not called bid'ah. Thus, the construction of the factories that exist today, the collection of the Qur'an, and the development of the state are not in the category of bid'ah.

Al-Imam asy-Syathibi said that the reasons put forward by the scholars who made mashlahah mursalah and istihsan as the basis for the acquisition of bid'ah are very inappropriate. This is because mashlahah mursalah itself is a method that arises from the demands of the 
proposition, but is not explained explicitly by the number of propositions that lead to it. So it is wrong to say that it is bid'ah (which has no basis in reason).

As for if anyone tries to connect the bid'ah that he made with the reason of mashlahah mursalah and istihsan, then AlImamasy-Syathibi argued because mashlahah mursalah is the object is not sharia but something that can still be reached by reason, while worship cannot always be reached by reason, so it does not make sense as the scope of mashlalah mursalah. The next rebuttal conveyed by Al-Imam asy-Syathibi related to the reason mashlahah mursalah and istihsan used by muabtadi is Al-Imam asy-Syathibi returning the meaning of istihsan to the definition brought by Al-Imam Malik and Al-Imam Abu Hanifah. With such defenisi maslahah mursalah and istihsan, mashlahah mursalah and istihsan included to the proposition used as a source of law. Automatically maslahah mursalah and istihsan cannot be used as a basis for the acquisition of heretical deeds hasanah.

\section{BIBLIOGRAPHY}

'Ali, 'Abdurrahman Adam. (1998). AlImam al-Syâthibiy:'Aqidatuhu Wa Mauqifuhu Minal Bida' Wa Ahliha (1st ed.). Maktabah ar-Rusydi.

Abadii, A. F. (2008). Qamusul Muhith. Darul Hadis.

Abdullah, T. (1996). Suplemen Ensiklopedi Islam. In islam. PT Ichtiar Baru Van Hoeve.

Al-'Abidi, H. (1992). الشاطبي ومقاصد الثريعة (p. 331). Darul Qutaibah.

Al-Ajfan, M. A. (1985). فتاوى الثاطبي.

Al-Basithi, A. S. A. bin M. al-K. (1932). Mu'alimu as-Sunan (Syarah Sunan Abu Daud). Mathba'ah 'Ilmiyah.

Al-Shabuniy, M. ' A. (1981). Shafwah alTafasir. Darul Qur'anul Karim.
Andriyaldi. (2013). Teori Maqashid Syari'ah Dalam Perspektif Imam Muhammad Thahir Ibnu 'Asyur. P3M STAIN Bukittinggi.

Araby, M. (2017). MENELISIK KONSEP BID'AH DALAM PERSPEKTIF HADIS. Jurnal Ilmiah Ilmu Ushuluddin, 15(1), 63-72. https:/ / doi.org/10.18592/JIU.V15I1.1 071

As-Syathibi, A. I. (1988). al-I'tisham. Darul Kutubil 'ilmiyyah.

Ash-Shabuni, S. M. A. (2011). Shafwatut Tafasir; tafsir-tafsir pilihan (L. Muslich Taman \& L. Ahmad Tarmidli (eds.); K. Yasin (trans.)). Pustaka al-Kautsar.

Aziz bin Abdi Salam, I. (2000). Al-Qawaid al-Kubro.

Dahlan, A. A. (1997). Ensiklopedi Hukum Islam. In Hukum Islam (p. 217).

Duski. (2006). Metode penetapan hukum islam menurut asy-sy ât ib $\hat{\imath}$. UIN Syarif Hidayatullah.

Fachrudin, A. H., \& Dkk. (2012). Ensiklopedia Bid'ah. Darul Haq.

Habibullah, E. S. (2017). Pandangan Imam Abu Hanifah dan Imam Syafi'i Tentang Al-Istihsan. Al Mashlahah Jurnal Hukum Dan Pranata Sosial Islam, $4(7), 456$.

Herawati, A. (2014). MASLAHAT MENURUT IMAM MALIK DAN IMAM AL-GHAZALI (STUDI PERBANDINGAN). DIKTUM: Jurnal Syariah Dan Hukum, 12(1), 42-53.

Manzhur, I. (1955). Lisanul Arab - حرف الام.53r. In Lisanul Arab. Dar Shadir.

Mubarok, G. (2008). Dan Ortodoksi Tafsir Sunni. UIN Syarif HIdayatullah.

Munawwir, A. W. (1997). al-Munawwir. Pustaka Progressif.

Nabilah, W., Warman, A. B., \& Octavia, N. 'Aini. (2021). ISTIHSAN DALAM LITERATUR SYAFI ' IYAH (TELAAH ISTIHSAN DALAM 
KITAB Al-MUSTA Ș FA AlGHAZALI). Juris (Jurnal Ilmiah Syariah), 20(1), 77-89.

Nazaruddin. (2017). Al-Mabhats. In Penelitian, Jurnal Agama, Sosial (Vol. 155, Issue 2).

Qadir, A., \& Saqqaf, A. (2003). Ringkasan Al-I'tisham (10th ed.). Media Hidayah. Rosyadi, I. (2013). Pemikiran Asy-Syatibi tentang Maslahah Mursalah. Profetika: Jurnal Studi Islam, 14(1), 79-89.

Sabki, S., Wibowo, bangun sarwo aji, \& Fr, M. huda. (2012). al I'tisham (E. Fr (ed.); keempat). Pustaka Azzam.

Shihab, M. Q. (2002). Tafsir al-Misbah: pesan,kesan dan keserasian al-Qur'an. Lentera Hati.

Sitanggal, K. A. U., \& Dkk. (1992). Terjemahan Tafsir al-Maraghi. PT.Karya Toha Putra.

Winarno. (2019). Eksistensi Istihsan dalam Istinbath Hukum Menurut Imam Hanafi. Jurnal Pengabdian Masyarakat, 2(Juni), 93-107. 